\title{
Detentiebeleving van strafrechtelijk gedetineerden zonder verblijfsrecht ${ }^{*}$
}

\author{
Mieke Kox, Steven de Ridder, An-Sofie Vanhouche, Miranda Boone \& Kristel Beyens
}

De detentiebeleving van mannelijke strafrechtelijk gedetineerden zonder verblijfsrecht krijgt weinig aandacht in de penologische literatuur.Dit kwalitatieve onderzoek naar de ervaringen van 16 gedetineerden zonder en 30 gedetineerden met verblijfsrecht toont aan dat het contact met de buitenwereld en de voorbereiding op de invrijheidstelling gecompliceerd(er) zijn en de communicatie met het personeel moeizamer is voor gedetineerden zonder verblijfsrecht. Dit heeft een negatieve invloed op hun detentiebeleving. Het betekent dat zowel de deprivatie- als de importtheorie van toepassing is op gedetineerden zonder verblijfsrecht, maar dat importaspecten - met name het niet beschikken over verblijfsrecht - de deprivatie substantieel en systematisch kunnen versterken en tot bijkomende uitsluitings- en isolatiemechanismen kunnen leiden.

\section{Inleiding}

België huurt sinds februari 2010 de penitentiaire inrichting (PI) Tilburg om de overbevolking in de Belgische gevangenissen enigszins te lenigen. In deze inrichting verblijven anno 2014 circa 650 mannelijke Belgische gedetineerden onder hoofdzakelijk Belgische penitentiaire regelgeving, gevoerd door voornamelijk Nederlands personeel onder leiding van een Belgisch-Nederlandse directie. Volgens de bevolkingslijsten van deze inrichting - die op dit punt overigens niet volledig geactualiseerd zijn (De Ridder \& Beyens, 2012) - had 53 procent van de gedetineerden geen rechtmatig verblijf op 24 februari 2012 (Beyens \& Boone, 2013 , 8). In België verblijven deze strafrechtelijk gedetineerden zonder verblijfsrecht samen met gedetineerden met rechtmatig verblijf in eenzelfde inrichting en hebben in beginsel dezelfde rechten en plichten.

Onderzoek van Beyens en Boone (2013) naar de ervaringen van gedetineerden en medewerkers met het Belgische detentieregime in de PI Tilburg laat zien dat gedetineerden het verblijf in de PI Tilburg doorgaans als positief ervaren, maar dat de detentiebeleving mede afhankelijk is van individuele kenmerken, zoals detentiefase, taal en verblijfsstatus. Dit geeft aanleiding te veronderstellen dat strafrechtelijk gedetineerden zonder verblijfsrecht het verblijf in detentie anders beleven dan gedetineerden met verblijfsrecht. Gezien het grote aantal gedetineerden zonder verblijfsrecht in de PI Tilburg en de toenemende tendens om gebruik te maken van strafrechtelijke detentie voor migranten zonder verblijfsrecht (Stumpf, 2006; Van der Leun \& Van der Woude, 2013) is inzicht in de detentie-

* De auteurs danken Wendy Mercelis, directielid van de PI Tilburg, voor de toegang tot en informatie over gedetineerden in de PI Tilburg en alle respondenten die ons voor dit onderzoek te woord hebben willen staan. 
beleving van deze groep van belang. Op basis van zestien semigestructureerde kwalitatieve interviews met gedetineerden zonder verblijfsrecht ${ }^{1}$ is daarom onderzocht hoe gedetineerden zonder verblijfsrecht het verblijf in de PI Tilburg ervaren.

Eerst wordt een kort overzicht gegeven van de bestaande penologische literatuur over detentiebeleving. Vervolgens wordt de gebruikte methodologie toegelicht. Hierna is bij de beschrijving van de resultaten achtereenvolgens aandacht voor - indien relevant - de juridische context in de PI Tilburg en de beleving van gedetineerden zonder verblijfsrecht.

\section{Detentiebeleving in de penologische literatuur}

Clemmer $(1940,299)$ introduceerde de term 'prisonisatie', die verwijst naar een assimilatieproces van gedetineerden aan de gevangeniscultuur, -gebruiken en -gewoonten. Goffman (1961) beschrijft de gevangenis als een totale institutie, waar gedetineerden tijdens hun opsluiting het risico lopen op mortificatieprocessen als gevolg van een verlies van privacy, autonomie en controle over het eigen leven. In de penologische literatuur zijn verder twee belangrijke verklaringsmodellen van detentiebeleving. Het deprivatiemodel stelt dat de beleving van detentie afhangt van de wijze waarop de persoon deprivaties in de gevangenis ervaart. Sykes (1958) beschrijft in dit kader vijf vormen van deprivatie - de zogenaamde 'pains of imprisonment' - waarmee gedetineerden tijdens hun vrijheidsontneming te maken krijgen, namelijk deprivatie van vrijheid, goederen en diensten, heteroseksuele relaties, autonomie en persoonlijke veiligheid. Naar aanleiding van de veranderingen in het gevangeniswezen en de wijzen waarop gedetineerden en personeel in inrichtingen met elkaar omgaan, beschrijft Crewe (2009; 2011) nog drie 'nieuwe pijnen', namelijk 'the pains of uncertainty and indeterminacy', 'the pains of psychological assessment' en 'the pains of self-government'. Hij doelt hiermee op de onzekerheid en onvoorspelbaarheid waarmee gedetineerden te maken krijgen als gevolg van onder meer de mogelijke vervroegde invrijheidstelling, de (discretionaire) bevoegdheden en hiermee gepaard gaande macht van het personeel en de beslissers, en de gedragskundige programma's en risicotaxaties waaraan gedetineerden onderworpen kunnen worden. Als reactie op de deprivatietheorie van Sykes stelt het importmodel dat de detentiebeleving en dit aanpassingsproces worden beïnvloed door de eigenschappen, ervaringen, subculturen, normen en waarden die gedetineerden de inrichting binnenbrengen (Irwin \& Cressey, 1962, 153). ${ }^{2}$

Het deprivatiemodel stelt dat de wijze waarop een gedetineerde zijn detentie beleeft en zich aan de gevangeniscultuur aanpast, bepaald wordt door de detentie-

1 In deze bijdrage wordt ten behoeve van de leesbaarheid gesproken over 'gedetineerden zonder verblijfsrecht'. Het betreft hier - tenzij expliciet anders aangegeven - gedetineerden die op strafrechtelijke titel gedetineerd zijn en geen rechtmatig verblijf genieten.

2 Voor een uitgebreidere toelichting van de beide modellen verwijzen we naar het inleidende artikel van dit themanummer. 
omstandigheden in de inrichting. Deze zijn een gevolg van de wijze van opsluiting en de organisatie van de inrichting. In later onderzoek wordt verondersteld dat factoren als beveiligingsniveau, (omvang van) de gevangenisbevolking, de hoeveelheid personeel in de inrichting en hun handelwijze, de strafduur, het regime en de (architectonische) gevangenisomgeving invloed hebben op de wijze waarop en de mate waarin deze vormen van deprivatie worden gevoeld (Van der Laan \& Eichelsheim, 2013; Liebling, 2004; Hochstetler \& DeLisi, 2005; Tasca e.a., 2010; Gover e.a., 2000; Beijersbergen e.a., 2012). Het is niet bekend hoe vorenstaande vormen van deprivatie zich tot elkaar verhouden en welke vormen van deprivatie als belangrijkste dienen te worden gezien.

Detentie-ervaringen van gedetineerden zonder verblijfsrecht zijn tot nog toe weinig onderzocht. De bestaande literatuur omtrent detentiebeleving richt zich hoofdzakelijk op buitenlanders (Van Kalmthout e.a., 2007; Tonry, 1997). Uit onderzoek van Snacken e.a. (2004, 50-69) blijkt dat buitenlanders in Belgische gevangenissen problemen ervaren op het gebied van communicatie, racisme, cultuurbeleving, activiteiten, begeleiding en invrijheidstelling. Dit heeft gevolgen voor het contact met personeel, de kennis van de huisregels, het verwerven van de gewenste zorg en de toekenning van sancties (Snacken, 2007). Ook Post (2005) maakt melding van communicatieproblemen bij etnische minderheden in Nederlandse inrichtingen: deze resulteren in een beperktere informatieoverdracht, bemoeilijkte medische zorgverlening, verminderde mogelijkheden om het geloof te belijden en beperktere toegang tot resocialisatiemogelijkheden. Dit is nefast voor het effectueren van hun rechtspositie (Post, 2005, 299). Singh Bhui (2007) stelt vast dat gebrek aan informatie over de detentieduur en de beperkte toegang tot familie en institutionele steun de detentiebeleving van buitenlandse gedetineerden in Britse inrichtingen negatief beïnvloeden. Janssen (1994) wijst tot slot op een combinatie van deprivatie- en importfacetten bij Latijns-Amerikaanse drugskoeriersters in de Nederlandse Bijlmerbajes: de vrouwen hebben vergelijkbare ervaringen en zoeken elkaar op vanwege hun gedeelde etniciteit en gepleegde delict, maar hun ervaringen lopen uiteen wegens verschillen in hun achtergrond.

Daarnaast is er - onder meer in Nederland - onderzoek uitgevoerd naar de ervaringen van migranten zonder verblijfsrecht in vreemdelingendetentie, een administratieve vorm van detentie ter fine van uitzetting. De detentiebeleving van administratief gedetineerde vreemdelingen wordt negatief beïnvloed door een sober regime met minimale activiteiten, strikte veiligheidsmaatregelen, het gevoel onvoldoende zorg te krijgen, beperkte juridische bijstand en een bemoeilijkt contact met de buitenwereld (Nationale ombudsman, 2012; Kox, 2007, 189-191; Van Kalmthout, 2007; Van Kalmthout e.a., 2004). Van Alphen e.a. (2013) stellen dat wanneer een toezichthouder meer werkt volgens een motiverende bejegeningsstijl - en dus meer stimuleert en ondersteunt - gedetineerden tevredener zijn over de omgang met het personeel, de dagbesteding, hun autonomie en de mate waarin zij respectvol worden behandeld. Uit recent Nederlands en Brits onderzoek naar migranten zonder verblijfsrecht in detentie blijkt dat de 
dreiging met uitzetting extra spanning en slapeloosheid met zich meebrengt (Kox \& Leerkes, 2013; Kox, 2007; 2011; Bosworth, 2012).

Vorenstaande geeft aanleiding te veronderstellen dat deprivatietheorieën ook van toepassing zullen zijn op strafrechtelijk gedetineerden zonder verblijfsrecht, maar dat de import van het gebrek aan verblijfstatus van groot belang zal zijn voor de beleving van de strafrechtelijke detentie.

\section{Methodologie}

In het onderzoek van Beyens en Boone (2013) werden in het voorjaar van 2012 zes gedetineerden zonder verblijfsrecht geïnterviewd. Daarbovenop zijn in de zomer van 2013 tien extra interviews gedaan, wat voor de analyse in het kader van dit artikel een selecte steekproef oplevert van zestien strafrechtelijk veroordeelde gedetineerden zonder verblijfsrecht die een straf uitzitten tussen drie en dertig jaar. Volgens gegevens verstrekt door de gevangenis zijn acht respondenten afkomstig uit Noord-Afrika, vijf respondenten uit Oost-Europa en het Midden-Oosten en twee respondenten uit Zuid-Amerika.

De topiclijst voor het halfopen interview is opgesteld aan de hand van de belangrijkste dimensies van Lieblings (2004) meetinstrument Measuring the Quality of Prison Life (MQPL), dat het morele klimaat in een gevangenis operationaliseert. De analyse focust zich op materiële leefomstandigheden, regime, contact met de buitenwereld, relaties met personeel en andere gedetineerden, persoonlijke ontwikkeling en resocialisatie, veiligheid en orde in de inrichting, eerlijkheid binnen de inrichting en toekomstverwachting. Tijdens de eerste zes interviews in 2012 is aan de hand van deze lijst ingegaan op de achtergrond van de gedetineerde, zijn verwachtingen over de PI Tilburg, de aspecten die de gedetineerde belangrijk vindt tijdens zijn detentie, waarom hij deze belangrijk vindt, en hoe de ervaringen in de PI Tilburg zich verhouden tot hun eerdere ervaringen in andere Belgische inrichtingen. Daarnaast is - als de gedetineerde dit zelf aankaartte - ingegaan op zijn vertrektraject. Voor de tweede serie interviews in 2013 is meer aandacht besteed aan het vertrektraject van de gedetineerde en de mogelijke invloed hiervan op zijn detentiebeleving. De interviews duurden gemiddeld anderhalf tot twee uur en vonden plaats in de spreekkamers van de PI Tilburg. Deze zijn - behoudens één interview waarbij wegens bezwaar van de respondent aantekeningen zijn gemaakt - opgenomen, getranscribeerd en door middel van het programma Maxqda geanalyseerd. We hebben vooral gefocust op de specifieke ervaringen van de gedetineerden zonder verblijfsvergunning en vergelijken deze, waar mogelijk of relevant, met de ervaringen van de volledige groep gedetineerden uit het onderzoek van Beyens en Boone (2013), zonder een systematisch vergelijkend onderzoek te ambiëren.

Door de kleine steekproef en de specifieke situatie in de PI Tilburg is de studie exploratief van aard en zijn de resultaten niet generaliseerbaar. Daarenboven vormen gedetineerden zonder verblijfsrecht geen homogene groep wat betreft her- 
komst, taalvaardigheid, terugkeerbereidheid, terugkeermogelijkheid en beschikbaarheid van steun van familie in België of het herkomstland, elementen waarop we niet vooraf hebben kunnen selecteren. Dit maakt dat zij tijdens de interviews verschillende thema's naar voren brachten en het verblijf in detentie in sommige opzichten verschillend beleefden.

\section{Detentiebeleving van gedetineerden in de PI Tilburg: empirische bevindingen}

De interviews met de gedetineerden met en zonder verblijfsrecht in de PI Tilburg laten zien dat zij het verblijf in deze inrichting in beginsel op vergelijkbare wijze beleven. Bij beide groepen komt veelvuldig naar voren dat zij tevreden zijn over het regime en de - relatief grote - hoeveelheid aan activiteiten die aangeboden worden, over de materiële omstandigheden die in Tilburg beter zijn dan in veel andere - oudere - Belgische inrichtingen waar ze eerder verbleven, en over het frequentere contact met het personeel. Daarnaast klagen beide groepen gedetineerden in gelijke mate over de medische dienst, die veelvuldig paracetamol voorschrijft en waarbij het moeilijk is om toegang tot een dokter te krijgen, over de voeding die uit magnetronmaaltijden bestaat, over de moeilijkheden bij het ontvangen van bezoek en over de beperktere mogelijkheden voor de voorbereiding van de invrijheidstelling (vgl. Beyens \& Boone, 2013). Hierna gaan we dieper in op de ervaringen van gedetineerden zonder verblijfsrecht (GZV).

\section{Contact met de buitenwereld}

Alle gedetineerden in de PI Tilburg hebben recht op minimaal drie keer per week bezoek, waarvan minstens één keer tijdens het weekend en op woensdagmiddag. Daarnaast hebben zij de mogelijkheid om via telefoon en post contact met de buitenwereld te onderhouden. ${ }^{3}$ Voor zowel gedetineerden met als gedetineerden zonder verblijfsrecht is het in de PI Tilburg lastiger dan in reguliere Belgische inrichtingen om contact met de buitenwereld te onderhouden, en in het bijzonder om bezoek te ontvangen. Dit heeft verschillende oorzaken, namelijk de afstand vanuit België naar Tilburg, de hogere kosten voor een bezoek aan Tilburg en de striktere aanmeldingsprocedure en planning voor het bezoek dan in de Belgische gevangenissen. Gedetineerden die regelmatig contact met de buitenwereld zeggen te onderhouden, noemen dit vaak het grootste minpunt van hun overplaatsing naar deze inrichting op Nederlands grondgebied.

Voorafgaand aan de huur van de inrichting verzekerde de toenmalige Belgische minister van Justitie dat voornamelijk gedetineerden die geen of weinig bezoek ontvingen naar de PI Tilburg overgeplaatst zouden worden (Belgische Senaat, Handelingen 2009/11). Indien een gedetineerde in de PI Tilburg gedurende drie maanden geen bezoek kan ontvangen, heeft hij de mogelijkheid om een zogenaamde bezoektransfer aan te vragen, dit wil zeggen dat de gedetineerde voor twee weken naar een Belgische inrichting wordt overgeplaatst waar familie en/of

3 Huishoudelijk Reglement PI Tilburg; art. 58-63 Basiswet betreffende het gevangeniswezen en de rechtspositie van de gedetineerden (Basiswet). 
vrienden de mogelijkheid hebben de gedetineerde veelvuldig te bezoeken. Deze bezoektransfer heeft echter veel nadelen volgens gedetineerden, die weinig kiezen voor deze optie. De weg via de gevangenis van Wortel is immers lastig en tijdrovend en ze lopen het risico om hun vertrouwde cel en arbeidsplaats in de PI Tilburg te verliezen.

Specifiek voor strafrechtelijke GZV is dat familieleden niet in Tilburg op bezoek kunnen komen omdat zij het Belgische grondgebied niet mogen verlaten doordat zij (ook) in afwachting van een uitspraak over hun definitief verblijf in België zijn. Bovendien is het voor respondenten zonder verblijfsrecht lastig om telefonisch contact met familie en/of vrienden in het herkomstland of een ander land buiten België te onderhouden door de hogere kosten die internationale gesprekken met zich meebrengen. ${ }^{4}$ Zo getuigt de volgende respondent:

'Ja, om de drie, vier maanden heb ik contact met mijn familie. Het is erg moeilijk. Soms heb ik niet genoeg geld... als je zin hebt om hen te spreken en je hebt de middelen niet.' (GZV4)

Gedetineerden zonder verblijfsrecht nemen soms geen contact op met hun familie in het herkomstland omdat de Dienst Vreemdelingenzaken (DVZ) - die over de uitzetting gaat - zowel telefoon- als bezoekerslijsten controleert. Het onderhouden van contact met familie en/of vrienden brengt dus een (verhoogd) risico op uitzetting met zich mee (De Ridder \& Vanquekelberghe, 2012), wat blijkt uit het volgende interviewfragment:

'Er zijn er velen, (...) die bellen zelfs niet naar hun familie. Uit angst dat $z e^{6}$ zouden weten van waar ze komen. Ze willen zelfs niet bellen naar hun familie. Ik ken er, zes jaar, die hun familie niet contacteren... Omdat ze schrik hebben om hun familie te contacteren, dat ze zouden weten... Bijvoorbeeld: hij is Marokkaan en hij zegt dat hij Algerijn is. Dat blijft Algerijn. En hij belt elke keer naar Marokko, dat wil zeggen dat hij liegt.' (GZV1)

Het contact met de buitenwereld is voor alle geïnterviewde gedetineerden echter een erg belangrijk - soms zelfs het belangrijkste - aspect van het verblijf in detentie. Dit blijkt bijvoorbeeld uit het verhaal van een respondent zonder verblijfsvergunning, die - omdat hij zijn gezin zo enorm mist - bereid is om zijn straf uit te zitten in een gevangenis in zijn herkomstland, ondanks dat de leefomstandigheden daar als veel minder goed bekendstaan. Contact met de buitenwereld is voor gedetineerden zonder verblijfsrecht extra van belang met het oog op het voorbereiden van de terugkeer en hun re-integratie: de familie in het herkomstland kan

$4 \quad$ Voor telefoongesprekken vanuit de PI Tilburg naar België wordt een Belgisch tarief gehanteerd.

5 De auteurs van dit artikel prefereerden om niet-vertaalde en ongecorrigeerde citaten te gebruiken, om enerzijds de authenticiteit van de citaten te bewaren en anderzijds inzicht te geven in het vervreemdende effect van het niet begrijpen van een andere taal. Op verzoek van de redactie zijn de citaten echter in het Nederlands vertaald. 
de gedetineerde helpen met het zoeken van onderdak en werk, wat de mogelijke terugkeer vergemakkelijkt.

\section{Voorbereiding op de invrijheidstelling}

Bij de invrijheidstelling van gedetineerden zonder verblijfsrecht wordt een onderscheid gemaakt tussen een justitiële en een administratieve fase (Jansen e.a., 2010). De justitiële fase is geregeld volgens de wet betreffende de externe rechtspositie van de veroordeelden tot een vrijheidsstraf en de aan het slachtoffer toegekende rechten in het kader van de strafuitvoeringsmodaliteiten van 2006 en omvat de toekenning van de strafuitvoeringsmodaliteiten en - tenzij de gedetineerde ervoor kiest zijn straf volledig uit te zitten (einde straf) - een aparte (voorlopige) invrijheidstellingsprocedure met het oog op uitzetting of uitlevering. De strafuitvoeringsmodaliteiten bestaan uit de door de minister van Justitie toegekende uitgaansvergunning of penitentiair verlof (strafonderbreking van respectievelijk 16 en 36 uur) en de door de strafuitvoeringsrechtbank (SURB) toegekende beperkte detentie en elektronisch toezicht. Deze strafuitvoeringsmodaliteiten moeten de gedetineerde in staat stellen zijn definitieve terugkeer naar de samenleving geleidelijk voor te bereiden. De administratieve fase is geregeld volgens de Vreemdelingenwet en beoogt de gedwongen uitzetting van het grondgebied van de onrechtmatig verblijvende gedetineerde vanuit de gevangenis of een gesloten centrum voor administratieve detentie.

Voor de toekenning van een uitgaansvergunning of penitentiair verlof maakt de wet juridisch geen onderscheid op basis van rechtmatig verblijf, waardoor deze ook aan gedetineerden zonder verblijfsrecht kunnen worden toegekend. ${ }^{7}$ Meerdere respondenten zonder verblijfsvergunning geven echter aan vanwege hun verblijfstatus niet in aanmerking te komen voor dergelijke strafuitvoeringsmodaliteiten en ervaren deze behandeling zelfs als discriminerend:

'Omdat ik geen Belg ben, een blanke, een Christen die voor de rechter komt. Zelfs pedofielen, hij heeft rare dingen gedaan maar hij is Belg. Zij hebben een [enkel]band, zij hebben verlof, ... Ik heb kleine dingen gestolen maar nee, negatief, negatief.' (GZV4)

Voor gedetineerden zonder verblijfsrecht is er wel een specifieke vorm van invrijheidstelling voorzien, die gericht is op uitzetting. Gedetineerden zonder verblijfsrecht met een straftotaal van drie jaar of minder worden door de gevangenisdirecteur in vrijheid gesteld. ${ }^{8}$ In Tilburg zitten vooral gedetineerden zonder verblijfsrecht met een straftotaal boven de drie jaar. Zij worden - behoudens het geval van strafeinde en met inachtneming van de tijdsvoorwaarden met betrekking tot de strafduur - in vrijheid gesteld door de SURB, die rekening houdt met vier contra-indicaties, te weten: (1) de kans op onderdak voor de veroordeelde, (2) het recidiverisico, (3) het risico dat de veroordeelde de slachtoffers lastigvalt, 
en (4) de door de veroordeelde geleverde inspanningen om de burgerlijke partijen te vergoeden. ${ }^{9}$ De SURB kijkt bij gedetineerden zonder verblijfsrecht hoofdzakelijk naar de eerste en de laatste contra-indicatie (De Ridder, 2012). In tegenstelling tot gedetineerden met verblijfsrecht dienen GZV geen reclasseringsplan voor te leggen aan de SURB. ${ }^{10}$

Voor de voorbereiding van de invrijheidstelling van gedetineerden zonder verblijfsrecht is het vanuit juridisch opzicht voldoende indien in onderdak voorzien kan worden. Enkele respondenten zonder verblijfsrecht stellen echter dat de SURB behalve onderdak ook andere elementen meeneemt:

'Woonst en werk, dat is het belangrijkste. En dat je jouw penale boete of gerechtskosten betaalt.' (GZV6)

'Ja ik heb adres, werkcontract en iemand die gaat voor jou zorgen (...) dat je niet gaat terugkomen.' (GZV7)

De elementen die de SURB meeneemt bij de toekenning van de invrijheidstelling - zoals scholing, arbeidscontract, vorming en begeleiding - moeten door gedetineerden gedocumenteerd worden. $\mathrm{Na}$ de voorwaardelijke invrijheidstelling volgen justitieassistenten het nakomen van de voorwaarden door de gedetineerden die rechtmatig in België verblijven op. Voor GZV die uitgezet worden, is niet in een justitiële follow-up in het herkomstland voorzien. Een respondent betwijfelt daarom de zinvolheid van deze documenten voor deze groep:

'Wat kan het hun schelen wat ik doe daar in (...)? Hoe kan je dat weten of die papier geldig is of niet? (...) Dat geeft eigenlijk geen zin voor illegale mensen die worden uitgezet om van al die papieren, die verwachtingen worden van hem gevraagd, dat heeft geen zin. Sommigen hebben gevraagd een Arabisch papier voor te werken van ergens, van Syrië. Wat heeft dat voor zin?' (GZV6)

Verschillende respondenten zonder verblijfsrecht wijzen erop dat het verkrijgen van de gevraagde documenten in het herkomstland niet evident is en om ze te verkrijgen is het van groot belang om in het thuisland over de nodige contacten te beschikken. Echter, ook als de gedetineerde banden met zijn herkomstland heeft kan het aanleveren van de vereiste documentatie bemoeilijkt worden door andere factoren:

'Ik heb met hem gesproken: "Ja nonkel, ik wil nog terug in de fabriek werken, alstublieft, maar ik heb een contract nodig om mij nog een kans te geven om mij terug naar (...) te laten komen."En dan euhm... Hij zegt: "Ja, ge moet niet zo daar of daar."Ik zei: "Nee, nonkel ik ben echt verander. Ik wil terugkomen naar (...) om mijn familie te verzorgen of zo."' (GZV7) 
Het betalen van de burgerlijke partij is tevens een belangrijk criterium om in aanmerking te komen voor de vervroegde invrijheidstelling. Aangezien de respondenten zonder verblijfsrecht tijdens hun verblijf in de samenleving uitgesloten waren van de reguliere arbeidsmarkt, zijn de middelen die ze ter beschikking hebben vaak gelimiteerd. Dit maakt het moeilijker om te voldoen aan deze contra-indicatie, zoals ook het volgende interviewfragment laat zien:

'The commission [SURB] can say I have to pay the money. But I have no money.' (GZV9)

De psychosociale dienst (PSD) - die in alle Belgische gevangenissen aanwezig is heeft een adviserende functie bij de invrijheidstelling van gedetineerden. De verslagen van de PSD zijn dan ook van groot belang voor gedetineerden. Zowel respondenten met als respondenten zonder verblijfsrecht maakten melding van het gebrek aan ondersteuning en beschikbare diensten om hun invrijheidstelling voor te bereiden, ook wegens de afwezigheid van de diensten in de PI Tilburg die hiervoor verantwoordelijk zijn (vgl. Beyens \& Boone, 2013). Een aantal respondenten zonder verblijfsrecht heeft echter minder mogelijkheden om zelf de terugkeer goed voor te bereiden vanwege het gebrek aan familie of kennissen in het herkomstland, het niet spreken van de taal uit het herkomstland door de migratie op jonge leeftijd, en door beperkte toegang tot organisaties in dit land. Niet iedereen heeft de mogelijkheid om hulp van familie of vrienden in te schakelen, maar familie biedt voor sommige gedetineerden uitkomst:

'Gelukkig heb ik familie die me helpt. Ik ga een beetje verder in het Zuiden, in de bergen. Daar is een beetje minder volk, minder volk. Daar een beetje tot ik aangepast ben. Beetje bij beetje, om alleen aan te passen. Enkel om uit de gevangenis te komen, heb je begeleiding nodig. Behalve lange tijd in België te hebben geleefd met een andere, de andere lang in de gevangenis en onmiddellijk terugkeren en leven in (...) na zo'n jaren.' (GZV1)

Sommige respondenten zijn in de veronderstelling dat hun irreguliere verblijfstatus een rol speelt bij het aantal contacten met de PSD en de intensiteit hiervan:

'Misschien omdat ze op voorhand weten, die mensen worden uitgezet, en hoeven zij niet zoveel inspanning te doen voor... Kan ik mij ook niet inbeelden over wat dat gaat (...). Dat noemt psychosociale begeleiding, maar eigenlijk zie ik geen.' (GZV6)

Een andere gedetineerde wijst erop dat de mogelijkheden van de PSD om de gedetineerden te helpen, beperkt zijn en dat deze vooral binnen de eigen landsgrenzen gelegen zijn:

'Maar als dat in België gaat, als iemand papieren heeft in België maar geen adres, ze kunnen wel een verblijfsplaats regelen. Niet een appartement of een 
huis, maar zo'n (...) speciale plaats waar daklozen of zo slapen. Dat kunnen ze wel regelen. Maar in [herkomstland] kunnen ze niet regelen.' (GZV8)

Daarbij is de vervroegde invrijheidstelling bij gedetineerden zonder verblijfsrecht niet alleen afhankelijk van het voorbereidende werk van de PSD en de uitspraak van de SURB, zoals bij andere gedetineerden, ook het uitzettingsproces speelt hierbij een rol. De uitzetting van een gedetineerde zonder verblijfsrecht is namelijk niet alleen afhankelijk van de terugkeerbereidheid en identiteitspapieren van de gedetineerde, maar tevens van de medewerkingsbereidheid van het herkomstland om bijvoorbeeld een 'laissez passer' te verstrekken. Dit is een extra bron van onzekerheid:

'Die SURB ja, er zijn nog niet echt dingen geweest. Want eh... Mensen hebben recht op een derde bijvoorbeeld of twee derde om vrij te gaan, maar in de meeste gevallen bij buitenlanders is het niet het geval. Zij zitten allemaal tot hun datum [strafeinde]. En sommige jaren over hun datum. En dat vind ik niet eh... niet terecht. Of eh... niet zo correct.' (GZV8)

Dit resulteert soms in frustratie onder respondenten, temeer omdat de PSD volgens hen weinig mogelijkheden heeft en/of weinig moeite doet om hen te helpen met hun voorbereiding op hun terugkeer naar de samenleving, om zo voor vervroegde invrijheidstelling in aanmerking te komen.

\section{I: 'En met uw invrijheidsstelling, helpt de PSD u?'}

R: 'Ze hebben mij niet geholpen. De gevangenis is zo. Ze gaan mij niet helpen een werk te zoeken, of iets dergelijk. Elke gevangenis heeft zijn systeem. Bijvoorbeeld andere gevangenissen, Marneffe, Saint-Hubert en zo. Je haalt een diploma, je komt buiten met een bewijs, je komt buiten met iets. Ik bijvoorbeeld, ik weet het niet. Een woning is al een probleem. Ik moet naar Italië vertrekken van zodra ik vrijkom. (...) Ze gaan mij niet vrijlaten. Ik heb geen papieren. Aangezien je geen papieren hebt, is het beter je voorlopige invrijheidsstelling te vergeten.' (GZV12)

Hoewel de uitzetting prioriteit geniet bij de invrijheidstellingsprocedure van gedetineerden zonder verblijfsrecht, houdt de PSD in zijn verslaggeving ook rekening met mogelijk recidivegevaar. Dit is een cruciaal element in zijn advies. De positieve inschatting van recidivegevaar is voor vele gedetineerden de reden dat ze niet voorwaardelijk in vrijheid worden gesteld. ${ }^{11}$ Zeker voor personen die reeds beslist hebben of zich erbij hebben neergelegd te moeten terugkeren, leidt dit tot frustratie:

'Vorige keer was alles positief, alleen van PSD negatief omdat ze zeggen: "Ja, te grote recidivegevaar." Maar als ik die vraag stel: "Recidivegevaar, waar? 
Want ik word uitgezet." "Ja, maar u kan nog altijd terugkomen." Als ik die bedoeling heb, kan ik na acht jaar ook terugkomen. [zucht] Maar is een grote conversatie met die PSD, altijd beloftes die ik niks waard vind omdat als je toch wilt terugkomen om iets te plegen.' (GZV6)

De bijkomende onzekerheid over de uitzetting die de GZV boven het hoofd hangt, geeft dus een extra element van onvoorspelbaarheid aan het verloop van hun detentie en meer emotionele stress. Ze dienen het eventuele vervroegd vrijkomen af te wegen tegen de identificatie en de mogelijke terugkeer naar het herkomstland. Deze onzekerheid raakt met name die respondenten die een uitzetting vrezen en die geen perspectief zien in het herkomstland:

'Verder geeft hij aan dat voor hem zijn familie belangrijk is. Hij geeft aan dat er wat problemen zijn omdat zijn familie waarschijnlijk in België mag blijven en hij misschien niet omdat hij een misdrijf pleegde. Dit baart hem veel zorgen omdat zijn kinderen in België opgegroeid zijn en altijd hier naar school zijn geweest en zelfs niet genoeg (...) praten om in [herkomstland] naar school te gaan.' (GZV11) ${ }^{12}$

Veel van deze respondenten vertellen slecht te slapen, veel na te denken en hoofdpijn te hebben:

\section{I: 'Die dreiging tot uitzetting, hoe is dat voor u?'}

R: 'Dat is moeilijk, mijn gevoel heeft echt moeilijk. Bijvoorbeeld gisteren slapen tot één uur en wakker tot zes uur. Om te denken ook aan mijn leven verder zonder jouw familie en zo. Nu die komen regelmatig op bezoek. Maar als ik ben in [herkomstland], die gaat niet komen hé. Elke keer, ik weet het niet in, vliegtuig of zo. Daarom ik denk veel. (...) Daarom ik kan niet slapen. Jij weet niet wat gaat gebeuren voor jou en zelf jij hebt ook [onverstaanbaar] als jij gaat verliezen, jij verliest alles. $\mathrm{Nu}$ als die gaat voor mij zeggen: "Jij hebt geen recht om hier te blijven" dan verlies ik alles. Mijn vrouw, mijn kinderen. Bijna alles hé.' (GZV10)

Er is een duidelijk verschil merkbaar tussen respondenten die uitkijken naar hun terugkeer en die een mogelijke uitzetting vrezen. Respondenten die niet willen terugkeren naar het herkomstland omdat ze daar geen perspectief zien om een veilig en/of welvarend leven op te bouwen, melden stress en spanning ten gevolge van de mogelijke uitzetting:

'Ik heb al een zelfmoordpoging gedaan. Nadien ben ik hier wakker geworden. Ik was bijna mijn been verloren. Nu zelfs als ze mij naar (...) sturen, wat gaan ze mij sturen? Dus dat is de miserie. Ik heb mijn dochtertje niet gezien, ik ben

12 Deze respondent gaf aan bezwaar te hebben tegen het opnemen van het gesprek. Tijdens dit interview zijn aantekeningen gemaakt, die later zijn verwerkt tot een interviewverslag. 
weggegaan bij mijn vriendin. We zijn acht jaar samen. Dus ik verkies te sterven in plaats van op het vliegtuig te stappen. Dat garandeer ik je.' (GZV12)

Dit gebrek aan perspectief en deze vrees maken dat deze respondenten er bewust voor kiezen om niet voor een vervroegde invrijheidstelling te gaan.

Respondenten die in hun herkomstland perspectief zien om een veilig en goed leven op te bouwen, melden in veel mindere mate stress. Zij gaan bovendien wel voor terugkeer naar het herkomstland, mede vanwege de vervroegde invrijheidstelling. Dit geldt ook voor de volgende respondent:

R: 'Ik heb die papieren getekend. Oké, ik heb geen keus. Dus zegt die advocaat: dat gaat toch niks geven. Dus heb ik getekend, vier jaar geleden, dat ik na detentie wanneer zij mij vrijlaten terugga naar mijn land van herkomst, terug naar (herkomstland).'

I: 'Hoe staat u daar tegenover? Denkt u daar al vaak aan?'

R: 'Oooh, denk ik vaak? Ik denk niet vaak. Waarom? Ik heb een huis daar, wij hebben nog onze eigendom daar. Dus als ik terug word gezet, dan ben ik niet op straat. Dus ik heb mijn familie, 90 procent van mijn familie is ook daar, en zoals neef en zo. Ik ben enige kind, dus ik heb geen broers en zus. En ja, hier is niet gelukt, ja. Verschillende reden, maar ja. Waarom en hoe hier is niet gelukt. Dus dat proberen, 't is juiste middel, dertig jaar. Misschien gaat het daar lukken. We zullen zien.' (GZV6)

\section{Communicatie}

Uit het literatuuroverzicht blijkt dat de relaties en de communicatie met het personeel een essentieel onderdeel zijn van de detentiebeleving van gedetineerden. Specifiek wat de PI Tilburg betreft laten Beyens en Boone (2013) zien dat de zogenaamde praatcultuur van de Nederlandse penitentiaire inrichtingswerkers (PIW'ers) de detentiebeleving positief beïnvloedt.

Taalbarrières hebben in deze context dan ook een extra invloed op de detentiebeleving. Het etnisch diverse Nederlandse personeel in de PI Tilburg spreekt - in tegenstelling tot het personeel in Belgische inrichtingen - relatief weinig Frans, terwijl veel gedetineerden zich vooral in het Frans uitdrukken en niet zelden geen Nederlands of Engels spreken. Voor aanvang van de huur van de Nederlandse inrichting besliste de Belgische Senaat dat alleen gedetineerden van Nederlandstalig gebied (gedwongen) naar de PI Tilburg overgeplaatst zouden worden en dat gedetineerden uit Franstalige inrichtingen hiertoe niet verplicht zouden worden (Belgische Senaat 2009/10, verslag 17 november 2009). In de praktijk komt echter een substantieel aantal gedetineerden uit de Waalse of Brusselse gevangenissen, met de nodige communicatieproblemen als gevolg.

Uit de interviews blijkt dat voornamelijk Franssprekende gedetineerden met taalproblemen te kampen hebben in de PI Tilburg. Dit geldt voor zowel gedetineerden 
met als gedetineerden zonder verblijfsrecht, al komen taalproblemen vaker voor bij GZV die nog niet zo lang in België of op Nederlands grondgebied verblijven. Zo stelt een van de respondenten zonder verblijfsrecht:

'Communicatie is hét probleem voor illegalen in de gevangenis.' (GZV1)

In de dagelijkse praktijk worden daarom vaak gedetineerden of personeelsleden als tolk ingezet om boodschappen van personeel aan gedetineerden over te brengen en vice versa. Voor de anderstalige respondenten biedt dit echter een beperkte oplossing voor hun communicatieproblemen. Dit leidt wel eens tot frustratie, zeker indien dergelijke communicatieproblemen - in de ogen van de gedetineerden - tot ongelijke behandeling leiden.

Taalproblemen spelen overigens niet enkel een rol bij contacten met het personeel, maar geven ook problemen bij het lezen en begrijpen van officiële Nederlandstalige documenten. Tijdens het verblijf in de inrichting krijgen gedetineerden zonder verblijfsrecht - in tegenstelling tot gedetineerden met verblijfsrecht doorgaans niet de mogelijkheid om Nederlands te leren, omdat zij België na hun straf dienen te verlaten. Dit maakt dat enkele geïnterviewde gedetineerden zonder verblijfsrecht zich benadeeld voelen tijdens het verblijf in detentie:

'Hier, ook die doen ook een beetje discriminatie voor mensen zonder papieren. Bijvoorbeeld als je wil studeren Nederlands, dat gaat niet als je geen recht hebt om hier te verblijven.' (GZV3)

Communicatieproblemen tijdens het verblijf in detentie kunnen aldus de detentiebeleving van anderstalige gedetineerden met en zonder verblijfsrecht negatief beïnvloeden. Echter, een aantal anderstalige gedetineerden vertelde ons zo weinig mogelijk contact met het personeel te willen onderhouden en dus weinig negatieve gevolgen van de beperkte communicatiemogelijkheden te ondervinden.

\section{Conclusie}

Voor deze bijdrage werden de specifieke problemen van strafrechtelijk gedetineerden zonder verblijfsrecht en de invloed daarvan op hun detentiebeleving onderzocht. Over het algemeen ondervinden gedetineerden zonder verblijfsrecht dezelfde deprivaties als gedetineerden met verblijfsrecht, maar de import van het gebrek heeft een bijkomend effect: het contact met de buitenwereld en de voorbereiding van de invrijheidstelling zijn gecompliceerd(er) en de communicatie met het personeel is moeizamer.

Hoewel alle gedetineerden klagen over het gebrek aan bezoek vanwege onder meer de geografische afstand en de extra kosten voor de reis naar Tilburg (vgl. Beyens \& Boone, 2013), is het risico op sociaal isolement voor gedetineerden zonder verblijfsrecht groter, zowel door moeizame contacten in de gevangenis als door moeizaam contact met de buitenwereld. De problemen zijn groter als de con- 
tactpersonen van de gedetineerde het Belgische grondgebied in afwachting van een uitspraak over hun verblijfsrecht niet mogen verlaten en/of de inrichting vanwege het gebrek aan rechtmatig verblijf niet kunnen bezoeken.

Ten tweede leiden de beperkte mogelijkheden voor GZV om hun invrijheidstelling voor te bereiden en de onduidelijkheid inzake hun invrijheidstellingsdatum, gecombineerd met een mogelijke uitzetting, tot verhoogde emotionele stress. Deze bevindingen geven verdere invulling aan Crewe's 'pain of uncertainty and indeterminacy'. Het gebrek aan verblijfstatus, dat vaak gepaard gaat met een gebrek aan middelen en sociaal kapitaal, belemmert bovendien de voorbereiding op hun terugkeer naar de samenleving. De procedurele complexiteit, onzekerheden en risico's leiden ertoe dat veel respondenten zonder verblijfsrecht er op een bepaald moment de brui aan geven en ervoor 'kiezen' om hun volledige straf uit te zitten in plaats van voor een vervroegde invrijheidstelling te gaan. Dit betekent niet zelden een substantiële verlenging van de detentietijd. Deze langere detentietijd versterkt op zijn beurt de verschillende vormen van deprivatie waar gedetineerden tijdens het verblijf in detentie mee te maken krijgen. Omdat ze 'niks meer te verliezen hebben', kan dit tot een vorm van onverschilligheid tijdens het verblijf in de gevangenis leiden, die maakt dat mogelijke conflicten met andere gedetineerden minder uit de weg worden gegaan. Geïnterviewde gedetineerden (met verblijfsrecht) die in het kader van de voorbereiding op hun invrijheidstelling wel belang hebben bij een vlekkeloos verloop van het verblijf in detentie zeggen deze gedetineerden daarom soms te mijden (vgl. Beyens \& Boone, 2013).

Ten derde zijn gedetineerden zonder verblijfsrecht vanwege het gebrek aan kennis van de Nederlandse taal niet in staat om gemakkelijk met het personeel te communiceren over dagelijkse aspecten van het gevangenisleven. Dit plaatst hen in een zwakkere positie, in het bijzonder in geval van conflicten waarbij verbale argumentatie belangrijk is. Taal- en communicatieproblemen bemoeilijken de relaties van deze gedetineerden met het personeel en verhogen het risico op de hiermee verbonden deprivaties.

Tot slot dient te worden opgemerkt dat gedetineerden zonder verblijfsrecht op financieel gebied vaak tot de minst bevoorrechte groep in de gevangenis behoren. Omdat ze weinig of geen bijkomende middelen van buiten krijgen, zijn ze afhankelijk van - in vergelijking met Belgische inrichtingen - de beperkte vergoeding die ze met de gevangenisarbeid in de PI Tilburg verdienen. Het beschikken over middelen voor de aankoop van onder meer bijkomende voedingswaren, tabak, telefoneren en televisie is echter niet alleen van belang om het leven tijdens de detentie aangenamer te maken, het gebrek hieraan leidt ook tot een lage(re) plaats binnen de gedetineerdenhiërarchie (vgl. Beyens \& Boone, 2013). Dit tezamen bevestigt de veronderstelling dat zowel de deprivatie- als de importtheorie van toepassing is op gedetineerden zonder verblijfsrecht, maar dat importaspecten - in dit geval het niet beschikken over verblijfsrecht - de deprivatie substantieel en systematisch kunnen versterken en tot bijkomende uitsluitings- en isolatiemechanismen binnen en buiten de gevangenis kunnen leiden. 
Sinds het onderzoek van Beyens en Boone (2013) is het aantal gedetineerden zonder verblijfsrecht in de PI Tilburg verder toegenomen. Op 19 januari 2014 heeft 59 procent van de populatie in deze inrichting geen recht op verblijf in België. ${ }^{13}$ Deze gedetineerden worden relatief vaak naar de PI Tilburg overgeplaatst vanwege de veronderstelling dat zij zich niet hoeven voor te bereiden op een terugkeer naar de Belgische samenleving en minder bezoek ontvangen dan gedetineerden met verblijfsrecht. Zij zouden hierdoor minder belang hebben bij detentie op Belgisch grondgebied. Dit onderzoek laat echter zien dat het verblijf in de PI Tilburg ook voor deze groep gedetineerden (meer) nadelen heeft, terwijl zij minder kunnen profiteren van het grootste voordeel van het verblijf in de PI Tilburg voor Belgische gedetineerden, namelijk de communicatie met het personeel. Het is dan ook de vraag of de oververtegenwoordiging van GZV op basis van vorenstaande veronderstelling kan worden gelegitimeerd.

\section{Literatuur}

Alphen, B. van, Molleman, T., Leerkes, A. \& Hoek, J. van (2013). Van bejegening tot vertrek. Een onderzoek naar de werking van vreemdelingenbewaring. Den Haag: WODC.

Beijersbergen, K., Dirkzwager, A., Laan, P. van der \& Nieuwbeerta, P. (2012). Zoeken naar de juiste bouwstenen. Het gevangenisontwerp en de detentiebeleving van gedetineerden. Tijdschrift voor Criminologie, 54(3), 211-231.

Beyens, K. \& Boone, M., m.m.v. Liefaard, T., Kox, M., Vanhouche, A. \& Poel, S. van der (2013). 'Zeg maar Henk tegen de chef.' Ervaringen met het Belgische detentieregime in de PI Tilburg. Den Haag: Boom Lemma uitgevers.

Bosworth, M. (2012). Subjectivity and identity in detention: punishment and society in a global age . Theoretical Criminology, 16(2), 123-140.

Clemmer, D. (1940). The prison community. New York: Holt, Rinehart and Winston.

Crewe, B. (2009). The prisoner society. Power, adaptation, and social life in an English prison. Oxford: Oxford University Press.

Crewe, B. (2011). Depth, weight, tightness: revisiting the pains of imprisonment. Punishment and Society, 13(5), 509-529.

Goffman, E. (1961). Asylums: essays on the social situation of mental patients and other inmates. Harmondsworth: Penguin.

Gover, A.R., Mackenzie, D.L. \& Armstrong, G.S. (2000). Importation and Deprivation Explanations of Juveniles' Adjustment to Correctional Facilities. International Journal of Offender Therapy and Comparative Criminology, 44, 450-467.

Hochstetler, A. \& DeLisi, M. (2005). Importation, deprivation, and varieties of serving time: An integrated-lifestyle-exposure model of prison offending. Journal of Criminal Justice, 33, 257-266.

Irwin, J. \& Cressey, D. (1962). Thieves, convicts and the inmate culture. Social Problems, 10(2), 142-155.

Jansen, H., Ridder, S. de \& Scheirs, V. (2010). Eindelijk vrij! Een terugkeer naar (n)ergens: de invrijheidsstelling van illegale gedetineerden. Fatik, 28, 6-15.

13 Schriftelijke informatie directie PI Tilburg. Hierbij dient de kanttekening geplaatst te worden dat de bevolkingslijsten waarop deze cijfers gebaseerd zijn, niet volledig geactualiseerd zijn (vgl. De Ridder \& Beyens, 2012). Dit kan betekenen dat het percentage gedetineerden zonder verblijfsrecht in de praktijk hoger uitvalt. 
Janssen, J. (1994). Latijnsamerikaanse drugskoeriersters in detentie: ezels of zondebokken? Arnhem: Gouda Quint.

Kalmthout, A.M. van (2007). Het regiem van de vreemdelingenbewaring: de balans na 25 jaar. Justitiële verkenningen, 33(4), 89-102.

Kalmthout, A.M. van, Hofstee-van der Meulen, F.B.A.M. \& Dünkel, F. (red.) (2007). Foreigners in European prisons. Volume 1 and 2. Nijmegen: Wolf Legal Publishers.

Kalmthout, A.M. van, Graft, A.M.W.J., Hansen, L.M.A. \& Hadrouk, M. (2004). Terugkeermogelijkheden van vreemdelingen in vreemdelingenbewaring. Nijmegen: Wolf Legal Publishers.

Kox, M. (2007). De menswaardigheid van de vrijheidsontneming van vreemdelingen in Nederland. Proces, 5, 186-193.

Kox, M. (2011), Leaving detention ... A study on the influence of immigration detention on migrants' decision-making processes regarding return. Den Haag: International Organisatie voor Migratie.

Kox, M. \& Leerkes, A. (2013). Met de schrik vrij? Een exploratief onderzoek naar de afschrikwekkende werking van vreemdelingendetentie. Tijdschrift over Cultuur \& Criminaliteit, 3(1), 47-68.

Laan, A. van der \& Eichelsheim, V. (2013). Juvenile adaptation to imprisonment: feelings of safety, autonomy and well-being and behaviour in prison. European Journal of Criminology, 10(4), 424-443.

Leun, J. van der \& Woude, M. van der (2013). A reflection on crimmigration in the Netherlands. In: M.J. Guia, M. van der Woude \& J. van der Leun (eds.). Social control and justice. Crimmigration in the age of fear. Den Haag: Eleven International Publishing, 41-60.

Liebling, A. (2004). Prisons and their moral performance. A study of values, quality and prison life. Oxford: Oxford University Press.

Nationale ombudsman (2012). Vreemdelingenbewaring: strafregime of maatregel om uit te zetten. Den Haag: Nationale ombudsman.

Post, M. (2005). Detentie en culturele diversiteit. Den Haag: Boom Juridische uitgevers.

Ridder, S. de (2012). Zijn vreemdelingenrecht en penitentiair recht verenigbaar? Beslissingen tot invrijheidsstelling van 'illegale' gedetineerden. Fatik. Tijdschrift voor Strafbeleid en gevangeniswezen, 30(135), 31-36.

Ridder, S. de \& Beyens, K. (2012). Incarcerated by numbers? Wat leren de cijfers ons over 'vreemdelingen' in de gevangenis? Panopticon, 33(4), 305-324.

Ridder, S. de \& Vanquekelberghe, C. (2012). De interactie tussen migratiebeleid en penaal beleid ten aanzien van gedetineerden zonder recht op verblijf in België. Proces, 6(91), 470-481.

Singh Bhui, H. (2007). Alien experience: foreign national prisoners after the deportation crisis. Probation Journal, 54(4), 368-382.

Snacken, S. (2007). Belgium. In: A.M. van Kalmthout, F.B.A.M. Hofstee-van der Meulen \& F. Dünkel (red.). Foreigners in European prisons. Volume 1. Nijmegen: Wolf Legal Publishers, 127-156.

Snacken, S., Keulen, J. \& Winkelmans, L. (2004). Buitenlanders in Belgische gevangenissen: knelpunten en mogelijke oplossingen. Brussel: Koning Boudewijnstichting.

Stumpf, J. (2006). The crimmigration crisis: immigrants, crime, and sovereign power. American University Law Review, 56(367), 367-419.

Sykes, G.M. (1958). The society of captives. A study of a maximum security prison. Princeton, NJ: Princeton University Press.

Tasca, M., Griffin, M. \& Rodriguez, N. (2010) The Effect of Importation and Deprivation Factor son Violent Misconduct: An Examination of Black and Latino Youth in Prison. Youth Violence and Juvenile Justice, 8(3), 234-249. 
Tonry, M. (1997). Ethnicity, crime, and immigration. In: M. Tonry (ed.). Ethnicity, crime, and immigration. Chicago: Chicago University Press, 1-29. 
Reproduced with permission of the copyright owner. Further reproduction prohibited without permission. 